УДК $332.14(571.65)$

\title{
АНАЛИЗ СОВРЕМЕННЫХ ТЕОРИЙ ПРОСТРАНСТВЕННОГО РАЗВИТИЯ КАК ОСНОВА ФОРМИРОВАНИЯ ЭКОНОМИКИ СЕВЕРО-ВОСТОКА РОССИИ (на примере Магаданской области)
}

\author{
Фавстрицкая О. С., Гальцева Н. В., Шарыпова О. А. \\ ФГБУН Северо-Восточный комплексный научно-исследовательский институт \\ им. Н. А. Шило ДВО РАН, г. Магадан \\ E-mail: favstritskaya@neisri.ru
}

\begin{abstract}
Рассмотрены современные концепции пространственного развития, которые определяют теоретическую и методологическую основу развития региональной экономики: от теорий регионального роста, основанных на производственной функции, до кластеров, учитывающих неоднородность территориальных систем, процессы концентрации экономики и расселения. Исследование теоретических концепций пространственного развития необходимо для поиска оптимальных механизмов территориальной организации северовосточных регионов России, имеющих свою специфику, обусловленную особенностями северной экономики - моноспециализацией, очаговой системой организации производства и расселения.
\end{abstract}

Ключевые слова: теории пространственного развития, северо-восточные регионы, Магаданская область.

DOI: $10.34078 / 1814-0998-2021-3-116-125$

\section{ВВЕДЕНИЕ}

В настоящее время в России продолжают происходить изменения в пространственной организации социально-экономических систем как на национальном, так и на региональном уровнях. В рамках обеспечения устойчивого и комплексного развития территорий все чаще подчеркивается необходимость стимулирования пространственного развития и формирования наиболее оптимальной структуры экономического пространства (Вызовы..., 2020).

Перед северо-восточными регионами России наиболее остро стоят задачи повышения конкурентоспособности и перехода экономики на инновационный путь развития, что в немалой степени зависит от обоснования наиболее эффективных пространственных форм организации производства и расселения. Для этого важно рассмотреть теоретические исследования, посвященные вопросам пространства в экономике; определить, какие из них получили наибольшее

(C) Фавстрицкая О. С., Гальцева Н. В., Шарыпова O. A., 2021 практическое применение и как с их помощью можно сформировать методологию эффективного пространственного развития для регионов Северо-Востока России.

\section{ДАННЫЕ И МЕТОДЫ ИССЛЕДОВАНИЯ}

Целью нашей работы является анализ современных теорий размещения, определяющих основные направления развития экономики не только ведущих стран мира, но и основы построения отечественного народнохозяйственного комплекса. Понимание основ современного пространственного развития позволит сформировать теоретическую основу, в рамках которой пространственное развитие северо-восточных регионов России будет наиболее эффективно.

Проведен анализ публикаций российских авторов, касающийся использования теории пространственного развития в региональной экономике (Жаркова, 2011; Мямлин, 2013; Носонов, 2015; Наумов и др., 2020). В исследовании были применены системный подход, методы сравнительного анализа и синтеза полученной информации. 


\section{РЕЗУЛЬТАТЫ ИССЛЕДОВАНИЯ И ИХ ОБСУЖДЕНИЕ}

Пространственный анализ как отдельное направление региональных экономических исследований появился в XIX в. И если первоначально исследователи искали пространственные закономерности развития только производительных сил, то с XX в. рассматривалась и непроизводственная сфера.

Базовыми теориями пространственного развития, от которых в той или иной степени отталкиваются современные теории, являются работы: И. Г. фон Тюнена, В. Лаунхардта, А. Вебера, А. Маршала, А. Пределя и Т. Паландера, Э. Хекшера и Б. Олина, В. Кристаллера, А. Леша, У. Айзарда, А. Р. Преда, Р. Гроца, Х. Хотеллинга, Г. Вернена и др.

Современные теории пространственного развития, основываясь на положениях базовых теорий, пытались устранить их недостатки. Так, большинство базовых теорий пространственного развития не учитывают вероятностные процессы в экономике. В целях устранения этого недостатка делались попытки корректировки статических теорий. Например, при выборе места размещения предприятий расширялось число учитываемых факторов.

Динамические теории размещения появились в первой половине ХХ в. В отличие от статических, в них рассматривают преимущественно многозаводские компании. Современные динамические теории сравнительно немногочисленны, и целостной динамической теории размещения к настоящему времени еще не сложилось.

Рассмотрим суть основных теорий пространственного развития.

\section{1. Западные теории регионального роста}

В неоклассической школе получила развитие региональная теория роста. Она основывается на производственной функции - учете роли различных факторов производства, включая технический прогресс. Наиболее разработанной является концепция Х. Зиберта, в которой объем потенциально возможного производства в регионе ставится в зависимость от таких видов затрат, как капитал, труд, земля и объем технических знаний; учитываются транспортные затраты и влияние особенностей социальной системы. Его выводы таковы: дифференциация в темпах роста региональных экономик определяется скоростью количественных изменений внутренних факторов развития (увеличением предложения рабочей силы, улучшением ее квалификации), важную роль играют направления миграции ресурсов (внутри страны и между государствами). Вклад каждой детерминанты в ускорение роста предлагается оценивать отдельно.
В неоклассических моделях роста выравнивание межрегиональных различий происходит путем перемещения капитала из высокоразвитых районов в менее развитые районы с большей доходностью капиталовложений, а трудовых ресурсов, наоборот, из менее развитых районов в высокоразвитые регионы с более высоким уровнем заработной платы. В поздних неоклассических моделях отношение к сближению уровня экономического развития регионов более осторожное. Факт немобильности природных свойств территории заставляет усомниться в правильности утверждений о возможности сближения уровней экономического развития разных регионов.

Кониеепичя «полюсов роста» представлена кумулятивными теориями полюсов роста, основанными на использовании только внутренних источников и ресурсов территориального развития, и новыми теориями полюсов роста, предлагающими перераспределение ресурсов между территориальными системами.

В кумулятивных теориях роста базовая модель принадлежит Г. Мюрдалю, который утверждает, что преимущества определенных местностей (полюсов роста) ведут к усилению их развития, в то время как отстающий регион может стать еще более отсталым. Он делает вывод, что рост экономики происходит неравномерно и уровни экономического развития территорий не сближаются.

Согласно теории «прямой и обратной связи» А. Хиршмана рост экономики в стране происходит несбалансированно. Такой рост может дать стимул для мобилизации потенциальных резервов в интересах развития.

Ф. Перру отвергает тезис о равноправии участников рынка (государств, территорий). «Полюса роста» Перру - это центры принятия решений и генерирования прибыли, которые в ходе своего развития оказывают благоприятный эффект на свою периферию (фирмы, территории). Перру считал, что задачей госрегулирования экономики является направленная политика на создание и поддержку полюсов роста и расширение зоны их влияния.

В концеепциии «полюсов роста» Ж. Р. Будвиля утверждается, что развитие производства не происходит равномерно во всех отраслях хозяйства, всегда можно выделить динамичные (пропульсивные) отрасли, которые являются стимулом развития всей экономики, представляя собой «полюса развития». Через систему отношений типа «затраты - выпуск» В. Леонтьева эффект нововведения передается на все хозяйство. Процесс концентрации производства сосредотачивает пропульсивные отрасли в определенной точке (районе, регионе) - «полюсе роста». Будвиль предложил иерархию полюсов роста, основан- 
ную на предложенной В. Кристаллером теории центральных мест. Он считал, что автономный рост присущ верхним иерархическим уровням центральных мест, тогда как рост низовых территориальных структур определяется механизмами диффузии нововведений.

Центральной идеей П. Потье является то, что территории, расположенные между полюсами роста и обеспечивающие транспортную связь, получают дополнительные импульсы роста благодаря увеличению грузопотоков, распространению инновации, развитию инфраструктуры. Поэтому они превращаются в оси (коридоры) развития, определяющие вместе с «полюсами роста» пространственный каркас экономического роста большого региона или страны.

Х. Р. Ласуэн выявляет особенности полюсов экономического роста (например, он считает, что полюсом роста может быть региональный комплекс предприятий, связанный с экспортом, а не только с ведущей отраслью). Однако он не указывает на конкретные каналы распространения импульсов роста к второстепенным отраслям экономики.

В модели Х. Ричардсона и П. Тонро региональный экономический рост - это процесс совокупной причинной обусловленности, в котором выгоды распределяются между теми регионами, которые уже находятся в благоприятном положении. И рыночные силы, и государственные инвестиции увеличивают неравенства в экономическом развитии регионов. В то же время предложенная модель не показывает способов уменьшения неравенства экономического развития регионов.

В теории Х. Ричардсона, касающейся городской агломерации основным фактором роста является скопление производственной деятельности в городах-крупных промышленных центрах (полюсах роста). По его мнению, именно региональная агломерационная экономика и личные предпочтения инвесторов играют ключевую роль, стимулируя технический прогресс и рост производительности труда, оказывая сильное воздействие на процессы размещения предприятий ${ }^{1}$. Основная составляющая в базовой модели Ричардсона - это локализация. Региональный рост базируется на внутренних немобильных ресурсах и привлечении мобильных ресурсов из других регионов. В модели учитываются также технический прогресс и социально-политические факторы.

Дж. Фридман в своей теории «цуентр - neриферия» также декларирует, что экономический рост концентрируется исключительно в городах.

${ }^{1}$ Первый эффект агломерации был рассмотрен А. Вебером в рамках его теории размещения.
Он выделяет четыре стадии формирования центров роста (ядер) в стране. Для описания развития периферийных территорий Дж. Фридманом, Т. Хермансеном и др. используется модель «диффузии нововведений», предложенная в 1950 г. Т. Хэгерстрандом.

Хэгерстранд обнаружил, что распространение информации в пространстве имеет свои законы и может быть смоделировано. Трансляционная способность региона зависит от инвестиционного климата. Согласно теории, весь процесс социально-экономического развития является следствием возникновения и распространения (диффузии) нововведений. Диффузия инноваций происходит от крупнейших метрополитенских центров к провинциальным населенным пунктам. Нововведения усиливают региональные различия, при этом они могут оказывать как отрицательное, так и положительное воздействие на развитие регионов.

$\mathrm{C}$ теорией диффузии инноваций тесно связана теория жизненного регионального цикла, которая рассматривает процесс производства товаров как процесс с несколькими стадиями. Наиболее благоприятным местом для размещения инноваций являются большие города, обеспечивающие больше персональных контактов. Активное производство может быть размещено в периферийных регионах, но это рискованно, поскольку вслед за стадией насыщения начинается снижение/прекращение производства, пока не появятся другие инновации в больших городах. В соответствии с этой теорией региональная экономическая политика должна концентрироваться на создании благоприятных условий для инновационной стадии в менее развитых регионах, например, в виде создания образовательных и научных центров (технополисы, наукограды).

Модель П. Кругмана (1953 г.) рассматривает страну, в которой существуют только два вида производства: сельское хозяйство и промышленность. Для сельского хозяйства характерно интенсивное использование земли и отсутствие эффекта от масштаба. Промышленность характеризуется возрастающей отдачей от масштаба и незначительным использованием земли. В силу эффекта масштаба промышленность будет располагаться в ограниченном числе городов, а наличие транспортных издержек будет побуждать ее выбирать те районы, где спрос на промышленную продукцию максимальный.

Идеи полюсов роста и диффузии инноваций получили свое логическое завершение в модели «вулкана» Х. Гирша. Крупная городская агломерация с ее развитой промышленностью и мощной научной базой характеризуется наиболее высоким уровнем доходов на душу населения, что обеспечивается периодическими импульса- 
ми инновационной деятельности. «Извержение» нововведений в таких «полюсах роста» сопровождается постепенным проникновением их на периферию. В результате уровень благосостояния отсталых районов постепенно повышается. Гирш указывает на периодичность импульсов нововведений, которые рано или поздно затухают, что превращает когда-то передовой центр в депрессивный старопромышленный район. В то же время со сменой больших циклов хозяйственной конъюнктуры ${ }^{2}$ могут возникать новые центры инноваций.

Похожие принципы излагаются в модели территориального развития новых районов, разработанной под руководством Э. Таафе на основе исследований П. Гоулда. Модель рассчитана для прибрежных государств на материках и может быть использована для описания развития любых малоосвоенных территорий, граничащих с развитыми регионами.

Теория экспортной базы (60-е гг. XX в.) объясняет экономический рост регионов значением экспорта в их экономике. Данная концепция отрицает возможность автономного развития за счет внутренних инвестиций и технического прогресса, не учитывает существование связи между степенью открытости регионального хозяйства и размером его внутреннего рынка. Незначительное внимание уделяется роли миграции людей и капитала.

Я. Тинберген, Х. Бос и их последователи в качестве основного фактора роста экономики рассматривают оптимальное размещение производства в центрах различных размеров. Оптимальность размещения достигается минимизацией производственных и транспортных издержек. Основным недостатком модели является отсутствие полного набора производственных и пространственных факторов, необходимых для объяснения регионального роста.

В 80-е гг. XX в. в Германии была сделана попытка создания «новой теории регионального роста». К. Криген-Боден, Х. Зиберт, Э. Боде и ряд других исследователей попытались синтезировать положения неоклассической школы и теории кумулятивного роста, дополнив их некоторыми идеями институционалистов, исследователей статических теорий размещения, внешней торговли, цикличности хозяйства. Было показано, что в крупных агломерациях цены на немобильные ресурсы всегда будут выше, чем на остальной территории. Ведущая роль процессов накопления капитала в региональном развитии отрицается, акцент смещается на совершенствование трудовых ресурсов (т. е. на накопление человеческого капитала). Доминирующим становится

${ }^{2}$ Описанных Н. Д. Кондратьевым и Й. Шумпетером. технический прогресс, выраженный в накоплении знаний, и увеличение расходов на НИОКР, а важнейшим импульсом - интенсивность инноваций в регионе.

В теории Д. Норта экономика функционирует в определенных институциональных границах, культура и идеология влияют на экономическое развитие. Важным элементом является понятие трансакционных издержек ${ }^{3}$. Для каждого общества существует уникальная система институтов, и поэтому может быть разработана стратегия действий, которая будет отвечать потребностям обособленной культуры общества и способствовать экономическому росту. Новый институционализм широко применяется при администрировании экономических реформ (Гульбина, 2004).

В 1990 г. М. Портер дал определение новой форме пространственной организации - кластеру. Кластер представляет собой концентрацию предприятий, способных достигать эффект синергии в силу близкого географического расположения и взаимозависимости. На современном этапе кластерный подход считается одной из наиболее оптимальных форм организации экономического пространства.

Теория Портера получила свое развитие в работах других западных экономистов, в том числе М. Энрайта (1993г.), П. Кругмана (1995 г.) и С. Розенфельда (1997 г.), рассматривавших процесс кластеризации с позиций сетевой экономики. Они расширили представление о кластере как об объекте, через который может осуществляться диффузия инноваций на другие процессы, эффекты и системы. В рамках данной теории формирование кластеров - это создание специальных платформ, где сочетаются последние достижения фундаментальной науки, научноисследовательские и опытно-конструкторские работы, проектные работы и высокотехнологичные производства.

Значимым результатом современных исследований в области кластерной экономики является концеепция «умной спецчиализацุии», сформулированная западными экономистами Д. Фореем, П. Давидом, Б. Холлом (2007-2009 гг.). Концепция заключается в поиске уникальных видов экономической деятельности для развития конкурентных преимуществ территорий с использованием существующей структуры региональной экономики. Принципами концепции «умной специализации» руководствовались при разработке стратегий инновационного развития в ряде стран Латинской Америки, Азии, в разработках

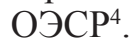
ВВП.

${ }^{3} \mathrm{~B}$ развитых экономиках они достигает половины

${ }^{4}$ Организация экономического сотрудничества и развития. 
Дальнейшее развитие теории кластеров связано с ориентацией на изучение нематериальных факторов размещения с применением инструментов институционального анализа, а также методов пространственного автокорреляционного и авторегрессионного моделирования.

\section{2. Пространственная организация экономики в $\mathrm{CCCP}$}

Советский опыт пространственной организации экономики формировался в условиях изолированности, специфики географии и полного государственного регулирования экономики. Исследования советских ученых были направлены на обоснование рационального размещения конкретных промышленных предприятий и комплексов и только потом на выведение общих законов размещения промышленности. Советская научная школа отличалась комплексностью и глобальностью решаемых задач.

Народное хозяйство страны рассматривалось как целостная система, а электрификация (план ГОЭЛРО 5 ) как отраслевой «полюс роста». В ходе реализации плана ГОЭЛРО было проведено экономическое районирование СССР в целях выделения доминирующих специализаций территорий и формирования на их основе локальных производственных комплексов. В стране существовал Совет по изучению производительных сил (СОПС), проводивший исследование природно-ресурсного потенциала страны для наиболее эффективного его использования и рационализации народного хозяйства.

Для понимания процесса пространственного развития России необходимо остановиться на отечественной теории размещения - теории территориально-производственных комплексов (ТПК), огромный вклад в создание и развитие которой внесли Н. Н. Колосовский, Н. Н. Баранский и М. К. Бандман.

В целом ТПК строились на основе факторов, предложенных А. Вебером (с учетом транспортной, рабочей и агломерационной «ориентаций»), но применительно к совокупности технологически смежных производств, сконцентрированных вокруг крупного промышленного предприятия (ядра). При этом в рамках ТПК отсутствовала конкуренция.

Создателем теоретической основы для развития региональной специализации в Советском Союзе является Н. Н. Баранский, в работах которого подробно описаны преимущества географического разделения труда и региональной специализации. Он дал первую характеристику хозяйства страны по экономическим районам Госплана.

\footnotetext{
${ }^{5}$ Государственная комиссия по электрификации России.
}

Н. Н. Колосовским сформулированы основные исходные положения о производственнотерриториальных сочетаниях и сделана попытка воплощения их в практику экономического районирования и комплексных предплановых территориальных исследований.

Инструментом экономической политики комплексного территориального развития народного хозяйства являлись Генеральные схемы размещения производительных сил СССР, призванные связать отдельные ТПК и отобразить народное хозяйство как систему. Данные схемы разрабатывались в СОПСе под руководством Н. Н. Некрасова. Схема каждой отрасли отрабатывалась отдельно и только затем связывалась со схемами других отраслей в генеральной схеме.

М. К. Бандман вплотную приступил к созданию теории формирования ТПК. Основные его исследования концентрировались на общей теории и практике размещения производительных сил страны, прогнозировании региональных систем, на вопросах освоения Сибири.

Целевыми закономерностями размещения советского хозяйства были: эффективное размещение производства, комплексное развитие экономических районов, рациональное территориальное разделение труда, выравнивание уровней экономического и социального развития регионов.

Размещение производительных сил строилось на принципах: приближения производства к источникам сырья, топлива, энергии и местам потребления продукции; равномерного размещения производства по территориям страны; специализации хозяйства отдельных регионов в целях максимального использования эффекта территориального разделения труда; комплексного развития регионов; укрепления обороноспособности страны и т. п.

Основными факторами размещения производительных сил считались: экономикогеографическое положение; население и трудовые ресурсы; производственный аппарат и инфраструктура; локализованные природные ресурсы; транспортный фактор; научно-технический потенциал; формы территориальной организации хозяйства; качество управления; социальный климат и др.

\section{3. Современные теории пространственного развития как теоретический базис трансформации экономики Северо-Востока России}

К началу реформ 90-х гг. ХХ в. пространственная организация регионов Северо-Востока России была выстроена на основе отечественной теории территориально-производственных комплексов. В размещении предприятий ключе- 
вого сектора экономики (добывающей промышленности) преобладал сырьевой фактор. В период существования СССР на основе плановой экономики была создана мощная производственная и социальная инфраструктура с ориентацией на постоянное заселение территории. Принцип рентабельности не учитывался, производства дотировались.

С переходом к рыночной системе хозяйствования, формируемой в рамках западных теорий размещения, изменились цели и принципы хозяйствования. Главным ориентиром для предприятий (отраслей) стала максимизация прибыли. Процесс приватизации радикально изменил роль госсектора в экономическом развитии регионов, за ним остались лишь функции услуг и поддержки инфраструктуры (Северная..., 1996). В рыночных условиях управление территорией перешло на региональный уровень и на органы местного самоуправления. Частный сектор получил полный доступ к реальному участию в хозяйственной деятельности страны, в том числе и к функции основного инвестора. Так, в Магаданской области только за период с 1980 по 1995 г. количество золотодобывающих предприятий увеличилось с 10 до 83 (Гальцева, 2009. С. 98).

Государство отстранилось от ведения геологоразведочных работ, что привело к существенному снижению их объемов. Добыча базировалась на отработке запасов, подготовленных в советский период. Лишь угроза масштабного снижения объемов добычи золота заставила частные компании начать инвестирование в геологоразведку.

Объективным фактором территориальной и структурной трансформации стало изменение административного деления Северо-Востока - в 1993 г. из состава Магаданской области выделился в самостоятельный субъект Чукотский автономный округ.

Специализация на добыче полезных ископаемых, монопрофильность и экспортоориентированность северо-восточных регионов страны сделала их переход к рыночным условиях хозяйствования болезненным. Новые условия функционирования добывающей отрасли (либерализация цен, зависимость добывающих отраслей от мировых рынков, необходимость осуществления геологоразведки своими силами и т. д.) отразились на политике освоения природных ресурсов северных территорий, на экономике и пространственном освоении регионов. Прежняя структура хозяйства была разрушена, а новая эффективная не создана.

Северо-восточные регионы России столкнулись с трудностями преодоления основных барьеров к развитию рыночного сектора в северной экономике, которыми являются повышенные производственные затраты, дефицит частных инвестиций, необходимость согласования прав на природопользование. Под влиянием конкуренции ряд отраслей в экономике регионов исчезли, ряд отраслей, напротив, получили ускоренное развитие. Так, в Магаданской области, специализирующейся на добыче золота и серебра, утрачена легкая промышленность, практически исчезло жилищное строительство. В то же время росли объемы оптовой и розничной торговли, стал возрождаться традиционный сектор народов Севера.

В таблице представлены объемы производства важнейших видов промышленной продукции, произведенной в Магаданской области за 1 день в 1990 и 1995 г. Данные таблицы наглядно демонстрируют падение производства в регионе в первые 5 лет построения рыночной экономики.

В зоне риска оказался средний и малый бизнес. За время перестройки в базовой отрасли Магаданской области появилось большое количество средних и мелких недропользователей, не обладающих достаточными техническими и финансовыми возможностями, которые не могли обеспечить эффективную добычу золота в регионе.

Результатом неэффективного развития северовосточных регионах стал дефицитный бюджет и масштабный отток населения. Так, дотационность бюджета Магаданской области составила в 2020 г. $37 \%$ (в последние 20 лет - около $50 \%$ ), миграция из региона в 4.1 раза выше среднего дальневосточного уровня. С 1989 г. население Магаданской области сократилось почти в 3 раза (138.99 тыс. чел. в 2021 г.). Доля городского населения сейчас составляет $96.1 \%$ (в 1989 г. - $83.8 \%$ ), в региональном центре (г. Магадане) проживает $71 \%$ населения. В регионе год от года уменьшается количество населенных пунктов: на начало 2020 г. их 77 и 27 из них - упраздненные и заброшенные ${ }^{7}$, на начало 2021 г. - уже $72^{8}$.

С начала рыночных реформ прошло более 30 лет, однако пространственная организация социально-экономических систем северовосточных регионов России не соответствует реальным требованиям современной экономики. Трансформация отраслевой и территориальной структуры продолжается под воздействием следующих процессов: отработки разведанных месторождений полезных ископаемых; низких темпов и малых объемов геологоразведочных работ;

${ }^{6} \mathrm{https}: / /$ habstat.gks.ru/news/document/112853

7 Данные из паспортов муниципальных образований Магаданской области.

${ }^{8}$ Магаданская область в цифрах. 2021: Крат. стат. сб. / Хабаровскстат. Магадан, 2021. 111 с. 
Таблица. Производство важнейших видов промышленной продукции - один день из жизни области

Table. Production of the most important types of industrial products: one day in the region's life

\begin{tabular}{|l|c|c|c|}
\hline \multicolumn{1}{|c|}{ Промышленная продукция } & 1990 г. & 1995 г. & Снижение, раз \\
\hline Электроэнергия, млн кВт · & 8.8 & 7.5 & 1.2 \\
\hline Теплоэнергия, тыс. Гкал & 13.7 & 6.1 & 2.2 \\
\hline Добыча угля, тыс. т & 5.3 & 4 & 1.3 \\
\hline Добыча золота, кг* & 88 & 66 & 1.3 \\
\hline Добыча серебра, кг* & 523 & 142 & 3.7 \\
\hline Улов рыбы и добыча других морепродуктов, т & 370.1 & 226.6 & 1.6 \\
\hline Конструкции и изделия сборные железобетонные, м & 771.8 & 31.5 & 24.5 \\
\hline Стеновые материалы, тыс. шт. усл. кирпича & 352.1 & 12.6 & 27.9 \\
\hline Мебель, тыс. руб. & 32.9 & 16.2 & 2.0 \\
\hline Товарная пищевая рыбная продукция, т & 264.7 & 154.7 & 1.7 \\
\hline Колбасные изделия, т & 18.1 & 2.4 & 7.5 \\
\hline Хлеб и хлебобулочные изделия, т & 78.4 & 31.6 & 2.5 \\
\hline Цельномолочная продукция, т & 188.8 & 32.3 & 5.8 \\
\hline Введено в действие жилых домов, м² общей площади & 532.9 & 52.3 & 10.2 \\
\hline Перевезено грузов, тыс. т & 242 & 47 & 5.1 \\
\hline Перевезено пассажиров, тыс. чел. & 196 & 113 & 1.7 \\
\hline
\end{tabular}

*Рассчитан суточный объем исходя из величины годовой добычи (1990 г.: золото - 32 т, серебро - 191 т; 1995 г.: золото - 24 т, серебро - 52 т). Источник: Магаданская область. 55 лет. Стат. сб. / Территориальный орган ФСГС по Магаданской области. Магадан, 2008. 43 с.

трудности привлечения инвесторов в новые инвестпроекты (велика стоимость инфраструктурной составляющей); потери высокопроизводительной рабочей силы; масштабного использования вахтового метода работы.

Новая пространственная организация социально-производственной сферы региона, на наш взгляд, должна ориентироваться на модернизацию социально-экономического развития регионов на основе диверсификации производства с учетом того, что в первую очередь будут реализовываться инвестиционные проекты в добывающей (базовой) отрасли (Гальцева и др., 2020). Важен выбор теоретического базиса, в рамках которой такая трансформация будет проводиться. С этой целью проанализируем преимущества и недостатки рассмотренных нами современных теорий пространственного развития.

Главным недостатком всех существующих теорий регионального роста является недостаточная опора на теории размещения предприятий.

Теории «полюсов роста» активно применяются сегодня при организации и размещении различных видов экономической деятельности в пространстве. Однако они эффективны только тогда, когда имеются тесные, устойчивые связи центров концентрации, локализации ресурсов с окружающим их пространством. Основными их недостатками являются: недооценка социальных аспектов развития и влияния процессов, проис- ходящих в мировой экономике; игнорирование новых форм пространственной организации экономической деятельности (промышленных, региональных кластеров, сетевизации экономики).

В российской действительности ориентация на теории «полюсов роста» приводит к централизации процессов локализации ресурсов, к наращиванию диспропорций в процессах территориального развития из-за недостаточного внимания к вопросам межтерриториальных взаимосвязей.

В отличие от теорий регионального роста теории кумулятивного регионального роста учитывают реальные региональные факторы (факторы размещения производства). Достоинствами кумулятивных теорий также являются: использование инноваций как фактора роста территорий; выравнивание межрегиональных уровней экономического развития путем диффузии нововведений и индустриализации; возможность практического применения; определение экономического роста как последовательного ряда сменяющих друг друга неравновесных состояний. Однако в них не учитываются значение малых предприятий и влияние транснациональных фирм, игнорируются необходимость внутренней согласованности региональной производственной системы и эффекты от масштаба рынка и несовершенной (монопольной) конкуренции.

В модернизированных пространственных теориях «полюсов роста» в отличие от кумулятив- 
ных есть преимущества: использование факторов пространственной экономики как внутренних источников развития регионов, неоиндустриализация старопромышленных регионов, расширение рынков сбыта и снижение барьеров входа на рынок, а также достижение эффекта возрастающей отдачи от масштаба производства в качестве основных причин появления агломерационных образований.

Рассмотренные теории не исключают, а взаимно дополняют друг друга, что говорит о необходимости обращения к устоявшимся теориям пространственного развития, а также поиска новых теоретико-методологических подходов при формировании единой методологической платформы, позволяющей эффективно реализовывать основные положения Стратегии пространственного развития России в северо-восточных регионах России.

\section{ЗАКЛЮЧЕНИЕ}

Пространственный анализ как направление региональных исследований появился в XIX в. Первоначально исследователи искали пространственные закономерности развития только производительных сил, с XX в. они рассматривали уже как производственную, так и непроизводственную сферу. Теории регионального роста представлены неоклассическими теориями, основанными на производственной функции, и теориями кумулятивного роста, являющимися синтезом неокейнсианских, институционалистских и экономико-географических моделей.

В неоклассической школе региональный рост определяется количеством и качеством природных ресурсов, общей численностью и квалификацией трудовых ресурсов, запасами капитала и уровнем технологии. Развитие национальной экономики рассматривается как результат эффективного распределения ресурсов между регионами. Темп развития национальной экономики задан, а развитие одного региона возможно лишь за счет других регионов.

Концепция «полюсов роста» представлена кумулятивными теориями полюсов роста, основанными на использовании только внутренних источников и ресурсов территориального развития, и новыми теориями полюсов роста, предлагающими перераспределение ресурсов между территориальными системами. Положения теории активно развивались в ХХ в. и до сих пор используются в отдельных странах при формировании и реализации стратегии пространственного развития, в том числе и в России.

Развитие кластерной теории можно изобразить в виде перехода от рассмотрения вопросов размещения отдельных предприятий к феномену локализации производства, от материальных факторов размещения к нематериальным. Дальнейшее развитие теории кластеров связано с ориентацией на изучение нематериальных факторов размещения с применением инструментов институционального анализа.

Анализ теорий и моделей пространственного развития показывает их большое количество и разнообразие. Однако эволюция их развития демонстрирует, что они все больше сближаются и становятся ориентированы на практическую сферу, в них наблюдается переход от статики к динамике (Тополева, 2019).

С переходом к рыночной системе хозяйствования изменилась структура экономики Магаданской области за счет сокращения предприятий обрабатывающей и легкой промышленности (производства стройматериалов, швейного производства, сельскохозяйственного производства). В связи с закрытием предприятий в районах области и масштабным использованием вахтового метода произошел переток населения в областной центр (38.7 \% в 1990 г. и 71.0 \% в 2020 г.). Проблемой пространственной организации стала неиспользуемая инфраструктура, созданная в советское время в населенных пунктах районов, a также жилищный фонд. Возникла необходимость расселения закрывающихся и неперспективных поселков, население которых не обеспечено работой. В результате произошедших изменений система пространственной организации экономики и социальной сферы регионов Северо-Востока должна быть трансформирована в рамках наиболее эффективной для их специфических условий теории.

Рассматриваемые нами теории создавались и объясняли развитие экономики в отдельной стране, учитывая ее особенности развития, поэтому прямое заимствование зарубежных теорий и моделей будет неэффективным, их необходимо адаптировать к условиям российской действительности (Гаджиев, 2009), в нашем случае к условиям северных регионов Дальнего Востока.

Для нынешнего уровня социально-экономического развития северо-восточных регионов России представляется возможным использование комбинированной модели, включающей в себя как положения неоклассических теорий, основанных на производственной функции, так и теорий кумулятивного роста, являющихся синтезом неокейнсианских, институционалистских и экономико-географических моделей, не исключая использование положений кластерной теории.

По нашему мнению, основными принципами, которые должны быть положены в теоретическую концепцию пространственного развития северовосточных регионов России, должны стать:

учет особенностей развития социально-экономических систем регионов Северо-Востока 
России, в том числе немобильность природных ресурсов и устаревшая инфраструктура;

сохранение за базовой горнодобывающей отраслью роли «полюса роста», от которого будет исходить диффузия инноваций в другие сферы;

учет жизненного цикла (возраста) базовой отрасли как полюса роста и в целом учет цикличности развития экономики;

формирование коридоров развития, которые вместе с населенными пунктами-полюсами роста будут формировать необходимый пространственный каркас регионов (как внутри региона, так и на уровне межрегиональных связей);

направленная государственная политика на создание и поддержку полюсов роста (отраслей, населенных пунктов) и расширение зоны их влияния;

использование положений концепции «умной специализации» как современного направления исследований в области кластерной экономики.

\section{ЛИТЕРАТУРА}

Bblзовы и политика пространственного развития России в XXI веке / ред. В. М. Котляков, А. Н. Швецов, О. Б. Гелезер. Москва : Товарищество научных изданий КМК, 2020. 365 с. С. 7.

Гаджиев Ю. А. Зарубежные теории регионального экономического роста и развития // Экономика региона. 2009. № 2. URL: https://cyberleninka.ru/article/n/ zarubezhnye-teorii-regionalnogo-ekonomicheskogorosta-i-razvitiya (дата обращения: 05.06.2021).

Гальцева Н. В. Предпосылки и перспективы реструктуризации экономики Магаданской области / отв. ред. Н. А. Горячев. Москва : КомКнига, 2009. 320 с.

Гальиева Н. В., Фавстриикая О. С., Шарыпова О.А. Модернизация социально-экономического развития регионов Северо-Востока России // Регионалистика. 2020. T. 7, № 5. C. 5-23. DOI: $10.14530 /$ reg.2020.5.5
Гульбина Н. И. Теория институциональных изменений Д. Норта // Вестник Том. гос. ун-та. 2004. № 283. URL: https://cyberleninka.ru/article/n/teoriyainstitutsionalnyh-izmeneniy-d-norta (дата обращения: 13.05.2021).

Жаркова Е. С. Экономические теории размещения производства: от штандорта к кластерам // Вестник Санкт-Петербургского университета. Экономика. 2011. № 1. URL: https://cyberleninka.ru/article/n/ ekonomicheskie-teorii-razmescheniya-proizvodstvaot-shtandorta-k-klasteram (дата обращения: 13.06. 2021).

Мямлин А. П. Фактор пространства в экономике: историографический анализ // Проблемы современной экономики. 2013. № 2 (46). URL: https://cyberleninka.ru/article/n/faktor-prostranstva-vekonomike-istoriograficheskiy-analiz (дата обращения: 25.07.2021).

Наумов И. В., Седельников В. М., Аверина Л. М. Эволюция теорий пространственного развития: принципиальные особенности и современные задачи исследований // Журнал экономической теории. 2020. № 2. URL: https://cyberleninka.ru/article/n/evolyutsiya-teoriyprostranstvennogo-razvitiya-printsipialnye-osobennostii-sovremennye-zadachi-issledovaniy (дата обращения: 03.08.2021).

Носонов А. М. Теория диффузии инноваций и инновационное развитие регионов России // Псковский регионологический журнал. 2015. № 23. URL: https:// cyberleninka.ru/article/n/teoriya-diffuzii-innovatsiy-iinnovatsionnoe-razvitie-regionov-rossii (дата обращения: 05.08.2021).

Северная экономика и радикальная реформа (американский опыт и российские реалии) / А. Н. Пилясов, С. Голдсмит, Г. Кнапп, Л. Д. Кресдж, Г. Н. Ядрышников. Магадан : СВКНИИ ДВО РАН, 1996. 180 с.

Тополева T. Н. Региональное развитие: новые теории // Juvenis scientia. 2019. № 6. URL: https:// cyberleninka.ru/article/n/regionalnoe-razvitie-novyeteorii (дата обращения: 10.08.2021).

Поступила в редакичию 16.08.2021 2.

\section{ANALYSIS OF MODERN SPATIAL DEVELOPMENT THEORIES AS THE BASIS FOR THE FORMATION OF NORTHEAST RUSSIA'S ECONOMY (Exemplified by Magadan Oblast)}

\section{O. S. Favstritskaya, N. V. Galtseva, O. A. Sharypova}

\section{North-East Interdisciplinary Scientific Research Institute n. a. N. A. Shilo, FEB RAS, Magadan}

The article considers modern concepts of spatial development, which determine the theoretical and methodological basis for the development of regional economy, from theories of regional growth, based on production function, to clusters that take into account the heterogeneity of territorial systems, the processes of economy concentration and settling. Studying theoretical concepts of spatial development is necessary for seeking optimal mechanisms for the territorial organization of Russia's northeastern regions, peculiar in monospecification, focal system for organizing production and settling, all typical for the northern economy.

Keywords: theories of spatial development, northeastern regions, Magadan Oblast. 


\section{REFERENCES}

Challenges and Policies for Russia Spatial Development in the 21st Century, 2020. Eds. V. M. Kotlyakov, A. N. Shvetsov, O. B. Gelezer. Moscow, KMK Scientific Press Ltd. [In Russian].

Gajiyev, Yu. A., 2009. Foreign Theories of Regional Economic Growth and Development, Economics of the Region. 2. URL: https://cyberleninka.ru/article/ n/zarubezhnye-teorii-regionalnogo-ekonomicheskogo-rosta-i-razvitiya (Accessed: 05.06.2021) [In Russian].

Galtseva, N. V., 2009. Prerequisites and Prospects for Restructuring the Economy of the Magadan Oblast, Ed. N. A. Goryachev. Moscow, ComBook [In Russian].

Galtseva, N. V., Favstritskaya, O. S., Sharypova, O. A., 2020. Modernization of the Socioeconomic Development of the Northeast Russia's Regions, Regionalistica. 7, 5, 5-23. DOI: 10.14530/reg.2020.5.5 [In Russian].

Gulbina, N. I., 2004. D. North's Theory of Institutional Changes, Tomsk State University Journal. 283. URL: https://cyberleninka.ru/article/n/teoriya-institutsionalnyh-izmeneniy-d-norta (Accessed: 13.05.2021) [In Russian].

Myamlin, A. P., 2013. Space Factor in Economics: Historiographic Analysis, PSE. 2 (46). URL: https://cyberleninka.ru/article/n/faktor-prostranstva-v-ekonomikeistoriograficheskiy-analiz (Accessed: 25.07.2021) [In Russian].
Naumov, I. V., Sedelnikov, V. M., Averina, L. M., 2020. Evolution of Spatial Development Theories: Principal Features and Modern Research Problems, ZHET. 2. URL: https://cyberleninka.ru/article/n/evolyutsiya-teoriy-prostranstvennogo-razvitiya-printsipialnye-osobennosti-i-sovremennye-zadachi-issledovaniy (Accessed: 03.08.2021) [In Russian].

Northern Economy and Radical Reform (American Experience and Russian Realities), A. N. Pilyasov, S. Goldsmith, G. Knapp, L. D. Kresge, G. N. Yadryshnikov. 1996. Magadan, NEISRI FEB RAS [In Russian].

Nosonov, A. M., 2015. Diffusion of Innovations Theory and Innovative Development of Russia's Regions, Pskov Journal of Regional Studies. 23. URL: https://cyberleninka.ru/article/n/teoriya-diffuzii-innovatsiy-i-innovatsionnoe-razvitie-regionov-rossii (Accessed: 05.08.2021) [In Russian].

Topoleva, T. N., 2019. Regional Development: New Theories, Juvenis Scientia. 6. URL: https://cyberleninka. $\mathrm{ru} /$ article/n/regionalnoe-razvitie-novye-teorii (Accessed: 10.08.2021) [In Russian].

Zharkova, E. S., 2011. Economic Theories of Production Placement: from Location to Clusters, Bulletin of Saint-Petersburg University Economics. 1. URL: https://cyberleninka.ru/article/n/ekonomicheskie-teoriirazmescheniya-proizvodstva-ot-shtandorta-k-klasteram (Accessed: 13.06.2021) [In Russian]. 